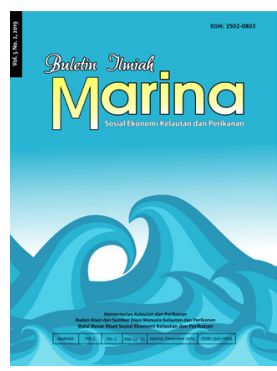

BULETIN ILMIAH MARINA

SOSIAL EKONOMI KELAUTAN DAN PERIKANAN

http://ejournal-balitbang.kkp.go.id/index.php/mra

p-ISSN: 2502-0803

e-ISSN: 2541-2930

Nomor Akreditasi: 10/E/KPT/2019

\title{
PULAU-PULAU KECIL SEBAGAI PUSAT PERTUMBUHAN EKONOMI DI WILAYAH PERBATASAN INDONESIA: Review Aspek Teknis, Sosial dan Ekonomi
}

\section{The Small Islands as a Center of the Regional Economic Growth in Indonesian Border Areas: Review of the Technical, Social and Economic Aspects}

\author{
*Suharyanto', Armen Zulham², Muhendis Sidqi', Arif Sudianto', Arif Widianto', \\ Suraji ${ }^{1}$, dan Didit Eko Prasetiyo ${ }^{1}$ \\ ${ }^{1}$ Direktorat Perencanaan Ruang Laut, Kementerian Kelautan dan Perikanan \\ JI. Medan Merdeka Timur Nomor 16 Jakarta Pusat, Indonesia \\ ${ }^{2}$ Balai Besar Riset Sosial Ekonomi Kelautan dan Perikanan \\ Gedung BRSDM KP I Lt. 4 \\ Jalan Pasir Putih Nomor 1 Ancol Timur, Jakarta Utara, Indonesia \\ Diterima tanggal: 23 April 2020 Diterima setelah perbaikan: 10 Mei 2020 \\ Disetujui terbit: 26 Juni 2020
}

\begin{abstract}
ABSTRAK
Potensi sumber daya hayati dan non hayati laut di Pulau-Pulau Kecil Terluar (PPKT) di Indonesia dapat menjadi pertumbuhan ekonomi kawasan perbatasan Indonesia. Saat ini, pertumbuhan ekonomi di kawasan perbatasan tersebut tertinggal dibandingkan di daratan. Potensi ekonomi kawasan PPKT mempunyai multiplier effect yang luas, membuka lapangan kerja, pendapatan, dan devisa jika dikelola dengan baik. Makalah ini bertujuan untuk mengidentifikasi potensi PPKT yang dapat menjadi pusat pertumbuhan ekonomi di wilayah perbatasan. Analisis skoring terhadap variabel-variabel penentu digunakan untuk mengidentifikasi sumber pertumbuhan ekonomi di PPKT. Hasil analisa menunjukkan terdapat 61 PPKT dari 111 pulau yang mempunyai potensi sebagai pusat pertumbuhan ekonomi di wilayah perbatasan. Enam puluh satu PPKT tersebut memiliki keunggulan bervariasi sebagai pusat pertumbuhan ekonomi. Hasil skoring terhadap variabel potensi pada 61 PPKT tersebut menunjukkan adanya 7 (tujuh) kelas prioritas pengembangan PPKT. Hasilnya,Pulau Tokong Belayar, Senua, Mangkai, dan Mantehage termasuk ke dalam PPKT kelas prioritas pertama. Kegiatan wisata bahari direkomendasikan sebagai kegiatan potensial untuk mengembangkan perekonomian PPKT yang dapat menyediakan lapangan kerja dan sumber pendapatan bagi masyarakat setempat serta berpeluang menambah devisa negara.
\end{abstract}

Kata Kunci: pulau kecil terluar; daerah perbatasan; wisata bahari; pusat pertumbuhan ekonomi

\begin{abstract}
Potency of renewable and non-renewable marine resources of Indonesian small islands could promote economic growth in Indonesian border areas. Currently, the economic growth of border areas have left behind compared with mainland areas. Potency of economy could give multiplier effect, create employment, income, as well as foreign exchanges when the resources are well managed. This study aimed to identify the potency of small islands that can be developed as center of economic growth in the border area. Scoring analysis to determinant variables were used to identify the source of economic growth in the small islands. The finding showed that there were 61 small islands of 111 small islands have the potency to be developed as economic growth center in border areas. Those 61 small islands
\end{abstract}


have 7 (seven) priority classes for small islands development. As the result, the island of Tokong Belayar, Senua, Mangkai, and Mantehage islands were included in first class priority. Finally, marine tourism becomes potential activity to develop the economy of small islands, create new jobs opportunity and income sources for local communities, as well as contribute the increase of foreign exchanges.

Keywords: small Islands; border area; marine tourism; central of economic growth

\section{PENDAHULUAN}

Indonesia memiliki 111 pulau-pulau kecil terluar (PPKT) dengan beragam potensi ekonomi yang telah diakui dunia melalui upaya ratifikasi United Nations Convention on The Law of the Sea (UNCLOS) 1982 dan diatur dalam Keputusan Presiden (Keppres) Nomor 6 Tahun 2017 tentang Penetapan Pulau-Pulau Kecil Terluar. Upaya ratifikasi UNCLOS tersebut dimaksudkan untuk: a) Memperkuat kedaulatan, pertahanan, dan keamanan negara dari ancaman eksternal pada wilayah perairan perbatasan dan PPKT; b) Implementasi hak berdaulat terhadap potensi sumber daya alam di perairan dan perairan laut dalam pada kawasan perbatasan; c) Implementasi hak berdaulat terhadap potensi ekonomi PPKT.

Beberapa PPKT yang terletak di perbatasan dengan negara lain seperti: Pulau Berakit (di perbatasan Singapura); Pulau Tokongmalangbiru, PulauTokongbelayar, Pulau Semiun (di perbatasan Malaysia); Pulau Sebetul (di perbatasan Vietnam); Pulau Ligayan, Pulau Solando (di perbatasan Malaysia dan Filipina); Pulau Bongkil, Pulau Mantehage, Pulau Makaheli (di perbatasan Filipina). Di perbatasan Republik Palau terdapat: Pulau Yiew Besar, Pulau Moff, Pulau Fani; di perbatasan Papua Nugini terdapat; Pulau Liki; di perbatasan Australia adalah Pulau Habe, Pulau Komolom, Pulau Laag, Pulau Kuriri; di perbatasan dengan Timor Leste terdapat Pulau Letti dan Pulau Kisar (Direktorat Perencanaan Ruang Laut, 2019). Kedaulatan territorial PPKT perbatasan mendapat perhatian dari pemerintah karena pulau-pulau tersebut memiliki potensi ekonomi dan pertahanan, seperti sejarah sengketa territorial Sipadan - Ligitan di perbatasan Indonesia dan Malaysia (Merrills, 2003; Butcher, 2013; Colson, 2003; Fareha, Victoria \& Apriliyanto, 2019). PPKT sebagai Kawasan Strategis Nasional Tertentu (KSNT) yang menjadi pilar untuk pertahanan, keamanan, kesejahteraan masyarakat, maupun menjaga kelestarian lingkungan hidup sesuai dengan Peraturan Pemerintah Nomor 62 Tahun 2010 tentang Pemanfaatan Pulau-Pulau Kecil Terluar (Sekretariat Negara, 2010).

Hasil penelitian mengenai potensi pengembangan PPKT sebagai pusat pertumbuhan ekonomi di wilayah perbatasan masih terbatas. Sementara informasi tersebut sangat penting untuk menyusun program dan kegiatan pembangunan di PPKT sebagai implementasi kebijakan dan strategi pembangunan di PPKT sebagaimana tertuang di dalam Rencana Pembangunan Jangka Menengah Nasional (RPJMN) 2020-2024. Perencanaan program/ kegiatan pembangunan di PPKT yang tepat, dapat mengurangi kesenjangan pendapatan antar wilayah di kawasan perbatasan Indonesia.

Sumber daya PPKT yang dipergunakan untuk penilaian potensi pengembangan PPKT dan penentuan urutan prioritas pengembangan PPKT sebagai pusat pertumbuhan ekonomi di wilayah perbatasan, meliputi: 1) ukuran luas daratan pulau, 2) keragaman dan kondisi ekosistem pesisir, 3) keberadaan penduduk di pulau, 4) aktivitas penduduk pulau dengan negara tetangga, 5) jarak/aksesibilitas ke lokasi pusat pertumbuhan ekonomi wilayah, 6) potensi sumber daya hayati laut untuk wisata bahari. Pembangunan kawasan perbatasan merupakan salah satu dari arah kebijakan pembangunan nasional yang digariskan di dalam RPJMN 2020-2024 dengan fokus terhadap pemenuhan pelayanan dasar, peningkatan aksesibilitas, dan pengembangan ekonomi yang mendukung pusat pertumbuhan wilayah di sekitarnya. Pusat pertumbuhan PPKT diharapkan memberikan pengaruh positif kepada pertumbuhan nasional, melalui Kawasan Ekonomi Khusus (KEK), Kawasan Industri (KI), Kawasan Pusat Bisnis/Pusat Bisnis (KPB/PB), Kawasan Strategis Pariwisata Nasional (KSPN), dan pusat pertumbuhan wilayah lainnya (Bappenas, 2019). Namun demikian, akses PPKT dari dan ke pusat pertumbuhan wilayah (KEK, KI, KPB/PB, KSPN) relatif terbatas. 
Kajian keterkaitan pembangunan antar kawasan atau desa-kota mengingatkan pada fenomena backwash effect karena disparitas pertumbuhan ekonomi akibat kebijakan pembangunan ekonomi (Lehtonen, Wuori, \& Muilu, 2015; Chiang, 2018; dan Azwar, Hamzah, Masbar, \& Syahnur, 2013). Pada kawasan PPKT, fenomena ekonomi backwash effect tersebut sudah terjadi terutama antara PPKT dengan pusat pertumbuhan ekonomi lokal, seperti: PPKT Nusa Penida, Rote, Selaru, dan Senua dengan pusat pertumbuhan ekonomi di sekitarnya. Demikian juga halnya pada PPKT yang berbatasan dengan negara tetangga, seperti PPKT Marore (Sulawesi Utara) dengan kota General Santos Filipina, PPKT Sebatik dengan Tawau (Sabah - Malaysia). Secara umum, backwash effect itu terlihat dari kekuatan pusat pertumbuhan ekonomi mengeksploitasi potensi sumber daya pada lokasi-lokasi PPKT yang disebutkan di atas.

Tujuan penelitian ini adalah mengidentifikasi potensi pengembangan ekonomi PPKT sebagai pusat pertumbuhan ekonomi di kawasan perbatasan. Pengumpulan data dilakukan melalui pemanfaatan data hasil survei toponimi di 111 PPKT pada tahun 2003-2009 (Direktorat Perencanaan Ruang Laut, 2019) dan survei penyusunan rencana zonasi Kawasan Strategis Nasional Tertentu (KSNT) PPKT tahun 2015-2019 (Kementerian Kelautan dan Perikanan (KKP) (2018; 2018a; 2017; 2016). Data yang dikumpulkan meliputi: luas daratan pulau, keberadaan dan kondisi ekosistem pesisir (mangrove, padang lamun, dan terumbu karang), jumlah penduduk yang bermukim di pulau, aktivitas penduduk pulau dengan negara tetangga, jarak dari pulau ke pusat kegiatan wilayah terdekat, jenis moda angkutan yang melayani penduduk pulau, serta kunjungan wisatawan ke pulau. Data dianalisis secara statistik deskriptif. Analisis variable potensi PPKT dilakukan melalui 5 tahapan, yaitu; menentukan kriteria, menentukan bobot, menentukan interval nilai, menghitung nilai skor variabel potensi, menetapkan ranking prioritas berdasarkan hasil skoring variabel potensi PPKT (Direktorat Perencanaan Ruang Laut, 2019).

\section{PEMBANGUNAN EKONOMI PPKT}

Teori pusat pertumbuhan yang dikembangkan sejak tahun 1600 -an oleh William Petty dan dilanjutkan oleh Francois Perroux tahun 1950 (Friedmann, 1967; Gavrilă-Paven \& Bele, 2017; Speakman \& Koivisto, 2013; dan Ogunleye, 2011) menjelaskan bahwa fenomena polarisasi pertumbuhan ekonomi karena perbedaan kekuatan ekonomi antar wilayah. Polarisasi pertumbuhan antara pusat pertumbuhan ekonomi dengan daerah pinggiran terjadi karena perbedaan kekuatan dan efisiensi fungsi-fungsi kegiatan (lapangan) usaha dalam perekonomian antara dua daerah tersebut. Kekuatan fungsi ekonomi tersebut antara lain: (a) aliran modal internasional; (b) aliran investasi asing berupa foreign direct invesment dan kehadiran investor multinasional; (c) jasa wisatawan dan tenaga kerja; serta (d) aliran barang konsumsi. Kawasan pusat pertumbuhan ekonomi yang memiliki fungsi ekonomi yang kuat mempunyai kemampuan untuk menarik/ mempengaruhi daerah pinggiran. Artinya, wilayah yang memiliki infrastruktur ekonomi yang baik akan mempengaruhi aktivitas perekonomian wilayah lain. Apabila PPKT dijadikan pusat pertumbuhan ekonomi, maka infrastruktur ekonominya harus kuat dan efisien agar dapat mempengaruhi kekuatan ekonomi pusat pertumbuhan ekonomi yang dekat dengan PPKT. Sektor pariwisata yang dipilih sebagai kegiatan yang dapat menumbuhkan ekonomi PPKT, maka sektor bisnis tersebut harus mempunyai koefisien keterkaitan ke belakang dan ke depan yang besar, agar PPKT dapat menjadi penentu pertumbuhan ekonomi daerah lain di sekitarnya.

Pariwisata menjadi salah satu potensi industri jasa di PPKT yang dapat digunakan untuk memanfaatkan potensi pasar bagi wisatawan nusantara dan wisatawan manca negara yang berpenghasilan menengah ke atas. Sektor ini berpotensi mendorong pertumbuhan ekonomi dengan cepat, jika infrastruktur dalam mendukung pengembangan ekonomi PPKT tersedia. Jasa wisata ini dapat membuka lapangan kerja baru, peningkatan pendapatan, dan devisa. Pariwisata berpotensi untuk mendorong perkembangan lapangan usaha lain dalam perekonomian nasional. Hasil kajian LPEM UI (2018) menunjukkan bahwa wisatawan domestik mengeluarkan belanja untuk jasa angkutan domestik sekitar $37 \%$, restoran dan rumah makan $22 \%$, belanja produk industri nonmakanan mencapai $15 \%$, serta hotel/akomodasi sebesar $10 \%$. Kajian tersebut sejalan dengan hasil analisis Nurhadi, Mardiyono, \& Rengu (2014) di Mojokerto yang menunjukkan bisnis jasa wisata dapat menumbuhkan bisnis jasa transportasi, akomodasi (hotel, motel, dan pondok wisata), restoran, industri kerajinan dan cendera mata, serta industri jasa-jasa keuangan. Industri jasa wisata tersebut selain mampu mendorong 
tumbuhnya berbagai usaha produksi barang dan jasa, juga menciptakan lapangan kerja baru dan memperluas lapangan kerja yang telah ada serta mampu menumbuhkan kawasan bisnis baru.

Penelitian Dewitri (2017) menunjukkan kontribusi lapangan usaha pariwisata pada perekonomian nasional sangat signifikan. Pada tahun 2014, kontribusi Lapangan Usaha Pariwisata terhadap Produk Domestik Bruto (PDB) mencapai 946,09 triliun rupiah (9\% dari PDB), lapangan usaha ini menyerap 11 juta tenaga kerja, dan menghasilkan devisa sebesar 120 triliun rupiah. Hasil penelitian ini dapat menjadi landasan untuk mengembangkan jasa pariwisata bahari sebagai penggerak perekonomian PPKT. Namun, pengelolaan jasa wisata di PPKT harus memperhatikan kelestarian ekosistem perairan di PPKT, agar jasa wisata tersebut dapat lestari dan berkelanjutan. Kerentanan ekosistem PPKT perlu diantisipasi terutama terkait dengan beberapa hal, yaitu: (a) rentan terhadap gangguan dari ekosistem daratan dan manusia; (b) rentan terhadap bencana alam; (c) sumber bahan organik alami dan tempat hidup keanekaragaman hayati; (d) nursery ground sebagai spesies endemik dan berbagai benthos; serta (e) rentan terhadap perubahan iklim dan cuaca (KKP, 2013).

Oleh sebab itu, membangun kawasan PPKT memerlukan komitmen dari berbagai pihak agar kebijakan, strategi, dan program pemerintah dapat menarik investor serta menarik wisatawan untuk datang dan membelanjakan pendapatannya di kawasan tersebut. Komitmen pemerintah diperlukan untuk tujuan strategis, yaitu; 1) menghindari eksploitasi potensi sumber daya alam di PPKT oleh negara tetangga yang mempunyai infrastruktur ekonomi yang lebih baik (Fadjri, 2018); 2) mengurangi menghilangkan ketergantungan pada infrastruktur ekonomi negara tetangga karena infrastruktur ekonomi kawasan PPKT sangat terbatas (Bank Indonesia, 2007; Kusumo, 2010; dan Bakce, Syahza, \&Asmit, 2018); 3) pengentasan kemiskinan karena kemiskinan merupakan permasalahan pembangunan yang dihadapi PPKT, yang disebabkan oleh lingkungan yang kurang baik, keterbatasan infrastruktur: pendidikan, kesehatan, komunikasi, aksesibilitas, dan kebutuhan pokok (Agvian, 2015); 4) mengoptimalkan PPKT sebagai lokasi untuk memantau pengawasan yurisdiksi laut Indonesia dari gangguan kejahatan di laut (Adiyanto, Eidman, \& Adrianto, 2007); 5) meningkatkan akses informasi, 6) indeks pembangunan manusia, produktivitas industri, dan investasi sektor industri unggulan kawasan PPKT relatif rendah (Kementerian PPS/Bappenas, 2017); 7) peningkatan kapasitas sumber daya manusia masyarakat PPKT (Redjo \& As'ari, 2017); serta 8) peningkatan sinergitas kebijakan antar lembaga dalam mengelola PPKT (Kusumo, 2010). Fenomena kesenjangan ekonomi di PPKT disparitas kualitas sumber daya manusia (SDM), infrastruktur ekonomi, dan relasi sosial yang berdampak pada eksploitasi di pusat pertumbuhan ekonomi PPKT. Sebagai contoh, penduduknya Pulau Miangas lebih banyak memenuhi permintaan pasar di Tibanban Davao Filipina (Pangalasen, 2013).

\section{POTENSI PULAU-PULAU KECIL DI PERBATASAN INDONESIA}

Berdasarkan hasil analisis, perhitungan penentuan kelas interval mengambil luas terendah 10.000 ha $\left(100 \mathrm{~km}^{2}\right)$ dan terbesar pada luas 1,87 juta ha $\left(18.700 \mathrm{~km}^{2}\right)$, maka diperoleh jangkauan data $(\mathrm{J}=256.082 \mathrm{ha}$ ). Banyaknya kelas ( $k$ ) dihitung dengan rumus $k=1+3,3 \log (N)$, dengan $\mathrm{N}=111$ (jumlah pulau), maka diperoleh interval nilai luas pulau-kategori $(k=8)$. Klasifikasi PPKT ke dalam 8 kelas interval luas (kategori) tersebut disederhakan menjadi 4 kelas interval luas untuk memudahkan analisis data. Tabel 1 menunjukkan bahwa ada $77 \%$ PPKT masuk dalam kategori luas < 106.027 ha, $12 \%$ dalam kategori luas $>298.093$ ha, 6\% dalam kategori luas antara 106.028 - 202.060 ha, dan $5 \%$ dalam kategori luas antara 202.061 - 298.092 ha. PPKT terkecil dengan luas 0,01 hektare adalah Karang Unarang, Batuberantai, Malangberdaun, Batugoyang, dan Batumandi. Sementara PPKT yang terluas adalah Pulau Kelepon yaitu 1,87 juta hektare (Tabel 1).

Berdasarkan Gambar 1, PPKT terbanyak (sebanyak 22 pulau) berada di Provinsi Kepulauan Riau, 19 pulau di Provinsi Maluku, 12 pulau di Provinsi Sulawesi Utara, 9 pulau di Provinsi Papua, sementara pada provinsi lainnya tercatat antara 1 sampai 9 pulau.

Jarak lokasi PPKT dengan pusat-pusat pertumbuhan ekonomi wilayah dalam negeri (PKN, PKW, PKL, KSN, KPB/PB, KSPN) dan pusat pertumbuhan ekonomi negara tetangga dikategorikan menjadi 3 (tiga) kelompok 
Tabel 1. Sebaran PPKT menurut Kelompok Luas Pulau dan Jumlah Pulau Berpenduduk dan Tidak Berpenduduk, 2019.

\begin{tabular}{cccc}
\hline No & $\begin{array}{c}\text { Interval Luas Pulau } \\
\text { (Hektare) }\end{array}$ & $\begin{array}{c}\text { Jumlah Pulau yang } \\
\text { Berpenduduk }\end{array}$ & $\begin{array}{c}\text { Jumlah Pulau yang tidak } \\
\text { Berpenduduk }\end{array}$ \\
\hline 1. & $<106.027$ & 36 & 49 \\
2. & $106.028-202.060$ & 3 & 4 \\
3. & $202.061-298.092$ & 2 & 4 \\
4. & $>298.093$ & 1 & 12 \\
\hline & Jumlah & $\mathbf{4 2}$ & $\mathbf{6 9}$ \\
\hline
\end{tabular}

Sumber: Data diolah dari Laporan Direktorat Pendayagunaan Pesisir dan Pulau-Pulau Kecil (2017) dan Direktorat Perencanaan Ruang Laut (2019)

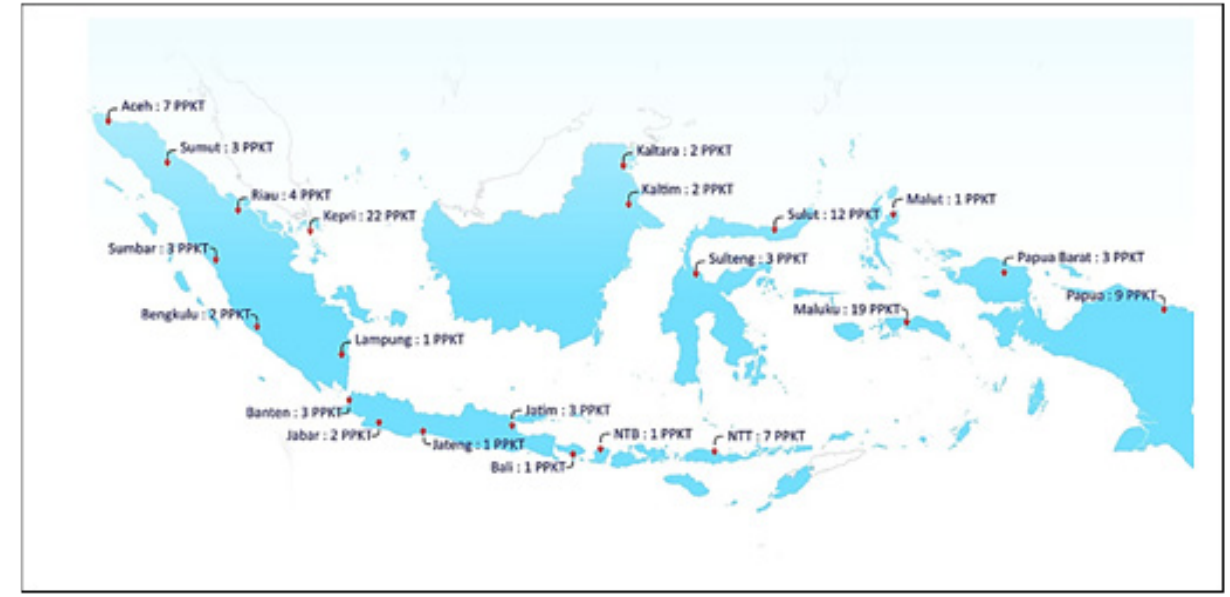

Gambar 1. Sebaran Lokasi 111 Pulau-Pulau Kecil Terluar di Indonesia, 2017.

Sumber: Direktorat Pendayagunaan Pesisir dan Pulau-Pulau Kecil (2019)

https://kkp.go.id/djprl/p4k/infografis -detail /5794-111-pulau-pulau-kecil-terluar-ppkt-di-indonesia

yang terdiri dari; 1) 44 pulau berjarak kurang dari $50 \mathrm{~km}, 2) 18$ pulau berjarak antara 50 hingga 100 km, dan 3) 49 pulau berjarak lebih dari $100 \mathrm{~km}$ (Tabel 2).

Moda transportasi yang dipergunakan untuk mencapai pusat pertumbuhan ekonomi wilayah yang berlokasi di sekitar PPKT adalah speed boat dengan kekuatan mesin 40-120 PK dan jumlah penumpang bervariasi mulai 15-50 orang, kecepatan 10-20 knot, (1 knot = 1,852 km/ jam), dan berperan memindahkan barang dan jasa dari dan ke PPKT. PPKT dengan jarak kurang dari $50 \mathrm{~km}$ memerlukan waktu tempuh kurang dari 2 jam untuk sampai di lokasi pusat pertumbuhan ekonomi wilayah terdekat. PPKT yang memiliki jarak lebih dari $100 \mathrm{~km}$ memerlukan waktu tempuh antara 5-10 jam. Semakin jauh jarak PPKT dari lokasi pusat pertumbuhan ekonomi wilayah terdekat, maka semakin rendah tingkat frekuensi hubungan penduduk di PPKT dengan pusat pertumbuhan ekonomi wilayah tersebut.

Hasil analisis keberadaan unsur-unsur ekosistem di perairan pesisir yang potensial untuk objek wisata bahari menunjukkan bahwa terdapat 61 pulau yang memiliki objek-objek wisata

Tabel 2. Jarak Lokasi PPKT dengan Pusat Pertumbuhan Ekonomi Wilayah, 2019.

\begin{tabular}{ccrcc}
\hline \multirow{2}{*}{ No. } & \multirow{2}{*}{ Kelompok Luas (ha) } & \multicolumn{3}{c}{ Jarak PPKT dengan Pusat Pertumbuhan Ekonomi Wilayah (km) } \\
\cline { 3 - 5 } & & $<\mathbf{5 0}$ & $\mathbf{5 0 - 1 0 0}$ & $>\mathbf{1 0 0}$ \\
\hline 1 & $<106.027$ & 35 & 13 & 37 \\
2 & $106.028-202.060$ & 4 & 1 & 2 \\
3 & $202.061-298.092$ & 1 & 2 & 3 \\
4 & $>298.093$ & 4 & 3 & 6 \\
\hline \multicolumn{2}{c}{} & Jumlah & $\mathbf{4 4}$ & $\mathbf{1 9}$
\end{tabular}

Sumber: Data diolah dari Laporan Direktorat Pendayagunaan Pesisir dan Pulau-Pulau Kecil (2017) dan Direktorat Perencanaan Ruang Laut (2019) 
Tabel 3. Keberadaan Potensi Ekosistem Pesisir di PPKT untuk Objek Wisata Bahari berdasarkan Kelompok Luas Pulau dan Jarak, 2019.

\begin{tabular}{|c|c|c|c|c|c|c|c|c|c|}
\hline \multirow{4}{*}{ No. } & \multirow{4}{*}{$\begin{array}{l}\text { Kelompok Luas } \\
\text { Pulau (ha) }\end{array}$} & \multicolumn{8}{|c|}{ Keberadaan Potensi Ekosistem Pesisir untuk Objek Wisata Bahari } \\
\hline & & \multicolumn{3}{|c|}{ Ada } & \multicolumn{5}{|c|}{ Tidak Ada } \\
\hline & & \multicolumn{3}{|c|}{$\begin{array}{l}\text { Jarak PPKT dari Lokasi } \\
\text { Pusat Pertumbuhan (km) }\end{array}$} & \multirow{2}{*}{ Jumlah } & \multicolumn{3}{|c|}{$\begin{array}{l}\text { Jarak PPKT dari Lokasi } \\
\text { Pusat Pertumbuhan (km) }\end{array}$} & \multirow{2}{*}{ Jumlah } \\
\hline & & $<50$ & $50-100$ & $>100$ & & $<50$ & $50-100$ & $>100$ & \\
\hline 1 & $<106.027$ & 16 & 7 & 22 & 45 & 19 & 6 & 15 & 40 \\
\hline 2 & $106.028-202.060$ & 3 & 1 & 1 & 5 & 1 & 0 & 1 & 2 \\
\hline 3 & $202.061-298.092$ & 1 & 2 & 1 & 4 & 0 & 0 & 2 & 2 \\
\hline 4 & > 298.093 & 2 & 2 & 3 & 7 & 2 & 1 & 3 & 6 \\
\hline & Jumlah & 22 & 12 & 27 & 61 & 22 & 7 & 21 & 50 \\
\hline
\end{tabular}

Sumber: Data diolah dari Laporan Direktorat Pendayagunaan Pesisir dan Pulau-Pulau Kecil (2017) dan Direktorat Perencanaan Ruang Laut (2019)

bahari yang potensial, yang meliputi; 1) 22 pulau berada pada jarak kurang dari $50 \mathrm{~km}, 2) 12$ pulau berada pada jarak antara $50-100 \mathrm{~km}, 3) 27$ pulau berada pada jarak lebih dari $100 \mathrm{~km}$ dari lokasi pusat pertumbuhan wilayah, dan 4) 50 pulau tidak potensial memiliki potensi wisata bahari (Tabel 3).

Relasi ekonomi yang dilakukan penduduk di PPKT dengan negara tetangga terdekat meliputi: hubungan sosial kekeluargaan, jual beli hasil kebun, hasil laut, atau pemenuhan barang-barang kebutuhan sehari-hari. Aktivitas ekonomi tersebut hanya terjadi pada pulau yang berpenduduk. Hasil analisis menunjukkan bahwa 42 PPKT berpenduduk terdapat 29 pulau yang memiliki aktivitas dengan penduduk di negara tetangga terdekat, dan 13 pulau lainnya tidak terjadi aktivitas ekonomi dengan pusat pertumbuhan ekonomi (Tabel 4).
Hasil analisis terhadap kriteria penilaian yang dipergunakan untuk mengukur potensi PPKT sebagai pusat pertumbuhan ekonomi terdiri dari kriteria fisik, sosial dan kriteria ekonomi. Kriteria kondisi fisik terdiri dari; (1) ukuran luas daratan pulau; (2) keragaman dan kondisi ekosistem pesisir. Kriteria kondisi sosial terdiri dari; (1) keberadaan penduduk pulau dan (2) aktivitas penduduk pulau dengan negara tetangga. Kriteria kondisi ekonomi adalah (1) jarak/aksesibilitas ke lokasi pusat pertumbuhan wilayah dan (2) potensi sumber daya hayati laut untuk wisata bahari. Masing-masing kriteria yang dievaluasi tersebut ditetapkan nilai kelasnya dengan interval nilai terendah 1 dan nilai tertinggi 7 (Tabel 5).

Hasil perhitungan bobot penilaian potensi pengembangan PPKT dengan cara matriks perbandingan berpasangan diperoleh bobot nilai seperti Tabel 6 .

Tabel 4. PPKT Berpenduduk yang Memiliki Aktivitas dengan Negara Tetangga berdasarkan Kelompok Luas Pulau dan Jarak, 2019.

\begin{tabular}{|c|c|c|c|c|c|c|c|c|c|}
\hline \multirow{4}{*}{ No. } & \multirow{4}{*}{$\begin{array}{l}\text { Kelompok Luas } \\
\text { Pulau (ha) }\end{array}$} & \multicolumn{8}{|c|}{ Aktivitas Penduduk dengan Negara Tetangga (Kekeluargaan, Jual Beli) } \\
\hline & & \multicolumn{3}{|c|}{ Ada } & \multicolumn{5}{|c|}{ Tidak Ada } \\
\hline & & \multicolumn{3}{|c|}{$\begin{array}{l}\text { Jarak PPKT dari Lokasi } \\
\text { Pusat Pertumbuhan (km) }\end{array}$} & \multirow[t]{2}{*}{ Jumlah } & \multicolumn{3}{|c|}{$\begin{array}{l}\text { Jarak PPKT dari Lokasi } \\
\text { Pusat Pertumbuhan (km) }\end{array}$} & \multirow[t]{2}{*}{ Jumlah } \\
\hline & & $<50$ & $50-100$ & $>100$ & & $<50$ & $50-100$ & $>100$ & \\
\hline 1 & $<106.027$ & 8 & 5 & 12 & 25 & 5 & 1 & 4 & 10 \\
\hline 2 & $106.028-202.060$ & 2 & 1 & 0 & 3 & 1 & 1 & 1 & 3 \\
\hline 3 & $202.061-298.092$ & 1 & 0 & 0 & 1 & 0 & 0 & 0 & 0 \\
\hline \multirow[t]{2}{*}{4} & $>298.093$ & 0 & 0 & 0 & 0 & 0 & 0 & 0 & 0 \\
\hline & Jumlah & 11 & 6 & 12 & 29 & 6 & 2 & 5 & 13 \\
\hline
\end{tabular}

Sumber: Data diolah dari Laporan Direktorat Pendayagunaan Pesisir dan Pulau-Pulau Kecil (2017) dan Direktorat Perencanaan Ruang Laut (2019) 
Tabel 5. Nilai Kelas Variabel untuk Evaluasi Potensi PPKT sebagai Pusat Pertumbuhan, 2019.

\begin{tabular}{|c|c|c|}
\hline Kriteria (Variabel) & Kelas Potensi & Nilai \\
\hline \multicolumn{3}{|l|}{ Ukuran luas daratan pulau } \\
\hline$<106.027$ & Kurang potensial & 1 \\
\hline $106.028-202.060$ & Cukup Potensial & 3 \\
\hline $202.061-298.092$ & Potensial & 5 \\
\hline$>298.093$ & Sangat Potensial & 7 \\
\hline \multicolumn{3}{|c|}{ Keragaman dan kondisi ekosistem pesisir } \\
\hline$<3$ ragam & Kurang Potensial & 1 \\
\hline $3-5$ ragam & Potensial & 5 \\
\hline$>5$ ragam & Sangat Potensial & 7 \\
\hline \multicolumn{3}{|c|}{ Keberadaan penduduk di pulau } \\
\hline Ada & Sangat Potensial & 7 \\
\hline Tidak Ada & Kurang Potensial & 1 \\
\hline \multicolumn{3}{|c|}{ Aktivitas penduduk pulau dengan negara tetangga } \\
\hline Ada & Sangat Potensial & 7 \\
\hline Tidak Ada & Kurang Potensial & 1 \\
\hline \multicolumn{3}{|c|}{ Jarak/aksesibilitas ke lokasi pusat pertumbuhan ekonomi wilayah } \\
\hline$<50 \mathrm{~km}$ & Sangat Potensial & 7 \\
\hline $50-100 \mathrm{~km}$ & Potensial & 5 \\
\hline$>100 \mathrm{~km}$ & Kurang Potensial & 1 \\
\hline \multicolumn{3}{|c|}{ Potensi sumber daya hayati laut untuk wisata bahari } \\
\hline$<3$ ragam & Kurang Potensial & 1 \\
\hline $3-5$ ragam & Potensial & 5 \\
\hline$>5$ ragam & Sangat Potensial & 7 \\
\hline
\end{tabular}

Sumber: Data diolah dari Laporan Direktorat Pendayagunaan Pesisir dan Pulau-Pulau Kecil (2017) dan Direktorat Perencanaan Ruang Laut (2019)

Tabel 6. Hasil Perhitungan Matrik Perbandingan Variabel, 2019.

\begin{tabular}{lc}
\hline \multicolumn{1}{c}{ Variabel } & Bobot \\
\hline Kriteria Fisik & 0,10 \\
\hline Ukuran luas daratan pulau & 0,28 \\
\hline Keragaman dan kondisi ekosistem pesisir & 0,04 \\
\hline Kriteria Sosial & 0,05 \\
\hline Keberadaan penduduk di pulau & \\
Aktivitas penduduk pulau dengan negara tetangga & 0,12 \\
\hline Kriteria Ekonomi & 0,42 \\
\hline Jarak/aksesibilitas ke lokasi pusat pertumbuhan ekonomi wilayah & \\
\hline
\end{tabular}

Sumber: Data diolah dari Laporan Direktorat Pendayagunaan Pesisir dan Pulau-Pulau Kecil (2017) dan Direktorat Perencanaan Ruang Laut (2019)

Bobot nilai dari Tabel 6 digunakan untuk mendapat nilai skoring dari 61 PPKT. Hasil skoring potensi pengembangan PPKT sebagai pusat pertumbuhan ekonomi di wilayah perbatasan dapat dipelajari pada Tabel 7 .

Kolom “Jumlah" pada Tabel 7 adalah nilai skor dari masing-masing PPKT yang mengindikasikan tingkat potensinya berdasarkan variabel-variabel yang dinilai pada masing-masing pulau. Semakin tinggi nilai menunjukkan tingkat kekuatan potensi pengembangannya sebagai pusat pertumbuhan ekonomi ke depan yang semakin kuat, demikian juga sebaliknya.

Langkah terakhir adalah menyusun interval kelas terhadap skor masing-masing PPKT untuk menentukan urutan prioritas kekuatan potensi PPKT sebagai pusat pertumbuhan ekonomi ke depan. Berdasarkan data pada Tabel 7 , interval diambil nilai terendah pada nilai skor 1,01 dan interval nilai terbesar pada nilai skor 6,47 , maka setelah dihitung diperoleh nilai tertinggi adalah 5,46 . 
Tabel 7. Hasil Skoring 61 PPKT sebagai Pusat Pertumbuhan Ekonomi di Wilayah Perbatasan, 2019.

\begin{tabular}{|c|c|c|c|c|c|c|c|c|c|c|c|c|c|c|}
\hline \multirow{4}{*}{ No } & \multirow{4}{*}{ PPKT } & \multicolumn{6}{|c|}{ Nilai Bobot Kelas Variabel Potensi } & \multicolumn{6}{|c|}{$\begin{array}{c}\text { Nilai Bobot Variabel x Nilai Kelas } \\
\text { Variabel }\end{array}$} & \multirow{4}{*}{ Jumlah } \\
\hline & & 0,10 & 0,28 & 0,04 & 0,05 & 0,12 & 0,42 & 0,10 & 0,28 & 0,04 & 0,05 & 0,12 & 0,42 & \\
\hline & & \multicolumn{6}{|c|}{$\begin{array}{c}\text { Nilai Kelas Variabel Penilaian } \\
\text { Potensi }\end{array}$} & $x$ & $\begin{array}{c}x \\
v^{2}\end{array}$ & $\begin{array}{c}x \\
y_{3}\end{array}$ & $\mathrm{x}$ & $x$ & $x$ & \\
\hline & & V1 & V2 & V3 & V4 & V5 & V6 & & & & & & & \\
\hline 1 & Moff & 1 & 1 & 1 & 1 & 1 & 1 & 0,10 & 0,28 & 0,04 & 0,05 & 0,12 & 0,42 & 1,01 \\
\hline 2 & Bras & 1 & 1 & 7 & 1 & 1 & 1 & 0,10 & 0,28 & 0,28 & 0,05 & 0,12 & 0,42 & 1,25 \\
\hline 3 & Pagai Utara & 1 & 1 & 7 & 1 & 1 & 1 & 0,10 & 0,28 & 0,28 & 0,05 & 0,12 & 0,42 & 1,25 \\
\hline 4 & Sebetul & 1 & 1 & 1 & 7 & 1 & 1 & 0,10 & 0,28 & 0,04 & 0,35 & 0,12 & 0,42 & 1,31 \\
\hline 5 & Sibarubaru & 5 & 1 & 1 & 1 & 1 & 1 & 0,50 & 0,28 & 0,04 & 0,05 & 0,12 & 0,42 & 1,41 \\
\hline 6 & Niau & 1 & 1 & 7 & 7 & 1 & 1 & 0,10 & 0,28 & 0,28 & 0,35 & 0,12 & 0,42 & 1,55 \\
\hline 7 & Subi Kecil & 1 & 1 & 7 & 7 & 1 & 1 & 0,10 & 0,28 & 0,28 & 0,35 & 0,12 & 0,42 & 1,55 \\
\hline 8 & Maratua & 1 & 1 & 7 & 7 & 1 & 1 & 0,10 & 0,28 & 0,28 & 0,35 & 0,12 & 0,42 & 1,55 \\
\hline 9 & Gili Sepatang & 1 & 1 & 1 & 1 & 7 & 1 & 0,10 & 0,28 & 0,04 & 0,05 & 0,84 & 0,42 & 1,73 \\
\hline 10 & Kawaluso & 1 & 1 & 7 & 7 & 5 & 1 & 0,10 & 0,28 & 0,28 & 0,35 & 0,60 & 0,42 & 2,03 \\
\hline 11 & Lingayan & 1 & 1 & 7 & 7 & 5 & 1 & 0,10 & 0,28 & 0,28 & 0,35 & 0,60 & 0,42 & 2,03 \\
\hline 12 & Penambulai & 1 & 1 & 7 & 7 & 5 & 1 & 0,10 & 0,28 & 0,28 & 0,35 & 0,60 & 0,42 & 2,03 \\
\hline 13 & Kabaruan & 1 & 1 & 7 & 7 & 7 & 1 & 0,10 & 0,28 & 0,28 & 0,35 & 0,84 & 0,42 & 2,27 \\
\hline 14 & Makalehi & 1 & 1 & 7 & 7 & 7 & 1 & 0,10 & 0,28 & 0,28 & 0,35 & 0,84 & 0,42 & 2,27 \\
\hline 15 & Sebatik & 1 & 1 & 7 & 7 & 7 & 1 & 0,10 & 0,28 & 0,28 & 0,35 & 0,84 & 0,42 & 2,27 \\
\hline 16 & Liki & 1 & 5 & 7 & 1 & 1 & 1 & 0,10 & 1,40 & 0,28 & 0,05 & 0,12 & 0,42 & 2,37 \\
\hline 17 & Simuk & 1 & 5 & 7 & 1 & 1 & 1 & 0,10 & 1,40 & 0,28 & 0,05 & 0,12 & 0,42 & 2,37 \\
\hline 18 & Bintan & 3 & 1 & 7 & 7 & 7 & 1 & 0,30 & 0,28 & 0,28 & 0,35 & 0,84 & 0,42 & 2,47 \\
\hline 19 & Salaut Besar & 5 & 5 & 1 & 1 & 1 & 1 & 0,50 & 1,40 & 0,04 & 0,05 & 0,12 & 0,42 & 2,53 \\
\hline 20 & Alor & 5 & 1 & 7 & 7 & 7 & 1 & 0,50 & 0,28 & 0,28 & 0,35 & 0,84 & 0,42 & 2,67 \\
\hline 21 & Habe & 1 & 7 & 1 & 1 & 1 & 1 & 0,10 & 1,96 & 0,04 & 0,05 & 0,12 & 0,42 & 2,69 \\
\hline 22 & Fanildo & 1 & 7 & 1 & 1 & 1 & 1 & 0,10 & 1,96 & 0,04 & 0,05 & 0,12 & 0,42 & 2,69 \\
\hline 23 & Miossu & 1 & 7 & 1 & 1 & 1 & 1 & 0,10 & 1,96 & 0,04 & 0,05 & 0,12 & 0,42 & 2,69 \\
\hline 24 & Kultubai Selatan & 7 & 5 & 1 & 1 & 1 & 1 & 0,70 & 1,40 & 0,04 & 0,05 & 0,12 & 0,42 & 2,73 \\
\hline 25 & Rusa & 1 & 5 & 1 & 1 & 7 & 1 & 0,10 & 1,40 & 0,04 & 0,05 & 0,84 & 0,42 & 2,85 \\
\hline 26 & Manggudu & 3 & 7 & 1 & 1 & 1 & 1 & 0,30 & 1,96 & 0,04 & 0,05 & 0,12 & 0,42 & 2,89 \\
\hline 27 & Larat & 1 & 1 & 7 & 1 & 1 & 5 & 0,10 & 0,28 & 0,28 & 0,05 & 0,12 & 2,10 & 2,93 \\
\hline 28 & Batubawaikang & 1 & 7 & 1 & 7 & 1 & 1 & 0,10 & 1,96 & 0,04 & 0,35 & 0,12 & 0,42 & 2,99 \\
\hline 29 & Batek & 1 & 7 & 1 & 7 & 1 & 1 & 0,10 & 1,96 & 0,04 & 0,35 & 0,12 & 0,42 & 2,99 \\
\hline 30 & Kakarotan & 1 & 5 & 7 & 7 & 5 & 1 & 0,10 & 1,40 & 0,28 & 0,35 & 0,60 & 0,42 & 3,15 \\
\hline 31 & Marampit & 1 & 5 & 7 & 7 & 5 & 1 & 0,10 & 1,40 & 0,28 & 0,35 & 0,60 & 0,42 & 3,15 \\
\hline 32 & Berakit & 1 & 5 & 1 & 7 & 7 & 1 & 0,10 & 1,40 & 0,04 & 0,35 & 0,84 & 0,42 & 3,15 \\
\hline 33 & Batuberantai & 1 & 5 & 1 & 7 & 7 & 1 & 0,10 & 1,40 & 0,04 & 0,35 & 0,84 & 0,42 & 3,15 \\
\hline 34 & Simeulue Cut & 7 & 5 & 1 & 1 & 7 & 1 & 0,70 & 1,40 & 0,04 & 0,05 & 0,84 & 0,42 & 3,45 \\
\hline 35 & Intata & 1 & 7 & 1 & 7 & 5 & 1 & 0,10 & 1,96 & 0,04 & 0,35 & 0,60 & 0,42 & 3,47 \\
\hline 36 & Berhala & 1 & 7 & 1 & 7 & 5 & 1 & 0,10 & 1,96 & 0,04 & 0,35 & 0,60 & 0,42 & 3,47 \\
\hline 37 & Rupat & 3 & 5 & 7 & 7 & 7 & 1 & 0,30 & 1,40 & 0,28 & 0,35 & 0,84 & 0,42 & 3,59 \\
\hline 38 & Nusapenida & 1 & 7 & 7 & 1 & 7 & 1 & 0,10 & 1,96 & 0,28 & 0,05 & 0,84 & 0,42 & 3,65 \\
\hline 39 & Sentut & 1 & 7 & 1 & 7 & 7 & 1 & 0,10 & 1,96 & 0,04 & 0,35 & 0,84 & 0,42 & 3,71 \\
\hline 40 & Putri & 1 & 7 & 1 & 7 & 7 & 1 & 0,10 & 1,96 & 0,04 & 0,35 & 0,84 & 0,42 & 3,71 \\
\hline 41 & Enggano & 1 & 1 & 7 & 1 & 1 & 7 & 0,10 & 0,28 & 0,28 & 0,05 & 0,12 & 2,94 & 3,77 \\
\hline 42 & Asutubun & 7 & 7 & 1 & 1 & 5 & 1 & 0,70 & 1,96 & 0,04 & 0,05 & 0,60 & 0,42 & 3,77 \\
\hline 43 & Wunga & 7 & 7 & 1 & 1 & 5 & 1 & 0,70 & 1,96 & 0,04 & 0,05 & 0,60 & 0,42 & 3,77 \\
\hline 44 & Damar & 1 & 1 & 1 & 7 & 1 & 7 & 0,10 & 0,28 & 0,04 & 0,35 & 0,12 & 2,94 & 3,83 \\
\hline 45 & Sambit & 1 & 1 & 1 & 7 & 1 & 7 & 0,10 & 0,28 & 0,04 & 0,35 & 0,12 & 2,94 & 3,83 \\
\hline 46 & Kepala & 1 & 1 & 1 & 7 & 1 & 7 & 0,10 & 0,28 & 0,04 & 0,35 & 0,12 & 2,94 & 3,83 \\
\hline 47 & Rote & 3 & 7 & 7 & 1 & 7 & 1 & 0,30 & 1,96 & 0,28 & 0,05 & 0,84 & 0,42 & 3,85 \\
\hline 48 & Kawio & 1 & 5 & 7 & 1 & 1 & 5 & 0,10 & 1,40 & 0,28 & 0,05 & 0,12 & 2,10 & 4,05 \\
\hline 49 & Nusabarong & 7 & 1 & 1 & 1 & 1 & 7 & 0,70 & 0,28 & 0,04 & 0,05 & 0,12 & 2,94 & 4,13 \\
\hline 50 & Enu & 7 & 1 & 1 & 1 & 1 & 7 & 0,70 & 0,28 & 0,04 & 0,05 & 0,12 & 2,94 & 4,13 \\
\hline
\end{tabular}




\section{Lanjutan Tabel 7.}

\begin{tabular}{|c|c|c|c|c|c|c|c|c|c|c|c|c|c|c|}
\hline \multirow{4}{*}{ No } & \multirow{4}{*}{ PPKT } & \multicolumn{6}{|c|}{ Nilai Bobot Kelas Variabel Potensi } & \multicolumn{6}{|c|}{$\begin{array}{c}\text { Nilai Bobot Variabel x Nilai Kelas } \\
\text { Variabel }\end{array}$} & \multirow{4}{*}{ Jumlah } \\
\hline & & 0,10 & 0,28 & 0,04 & 0,05 & 0,12 & 0,42 & \multirow{3}{*}{$\begin{array}{c}0,10 \\
x \\
v 1\end{array}$} & \multirow{3}{*}{$\begin{array}{c}0,28 \\
x \\
V 2\end{array}$} & \multirow{3}{*}{$\begin{array}{c}0,04 \\
x \\
V 3\end{array}$} & \multirow{3}{*}{$\begin{array}{c}0,05 \\
x \\
\mathbf{V} 4\end{array}$} & \multirow{3}{*}{$\begin{array}{c}0,12 \\
x \\
\text { V5 }\end{array}$} & \multirow{3}{*}{$\begin{array}{c}0,42 \\
x \\
\text { V6 }\end{array}$} & \\
\hline & & \multicolumn{6}{|c|}{$\begin{array}{c}\text { Nilai Kelas Variabel Penilaian } \\
\text { Potensi }\end{array}$} & & & & & & & \\
\hline & & V1 & V2 & V3 & V4 & V5 & V6 & & & & & & & \\
\hline 51 & Yiew Besar & 1 & 7 & 1 & 1 & 1 & 5 & 0,10 & 1,96 & 0,04 & 0,05 & 0,12 & 2,10 & 4,37 \\
\hline 52 & Deli & 7 & 1 & 1 & 1 & 5 & 7 & 0,70 & 0,28 & 0,04 & 0,05 & 0,60 & 2,94 & 4,61 \\
\hline 53 & Nuhu Yut & 1 & 5 & 7 & 1 & 7 & 5 & 0,10 & 1,40 & 0,28 & 0,05 & 0,84 & 2,10 & 4,77 \\
\hline 54 & Karang & 7 & 5 & 1 & 1 & 1 & 7 & 0,70 & 1,40 & 0,04 & 0,05 & 0,12 & 2,94 & 5,25 \\
\hline 55 & Bongkil & 1 & 7 & 1 & 7 & 7 & 5 & 0,10 & 1,96 & 0,04 & 0,35 & 0,84 & 2,10 & 5,39 \\
\hline 56 & Tokongnanas & 1 & 5 & 1 & 7 & 7 & 7 & 0,10 & 1,40 & 0,04 & 0,35 & 0,84 & 2,94 & 5,67 \\
\hline 57 & Batugoyang & 1 & 7 & 1 & 1 & 5 & 7 & 0,10 & 1,96 & 0,04 & 0,05 & 0,60 & 2,94 & 5,69 \\
\hline 58 & Tokongbelayar & 1 & 7 & 1 & 7 & 7 & 7 & 0,10 & 1,96 & 0,04 & 0,35 & 0,84 & 2,94 & 6,23 \\
\hline 59 & Senua & 1 & 7 & 1 & 7 & 7 & 7 & 0,10 & 1,96 & 0,04 & 0,35 & 0,84 & 2,94 & 6,23 \\
\hline 60 & Mangkai & 5 & 7 & 1 & 7 & 5 & 7 & 0,50 & 1,96 & 0,04 & 0,35 & 0,60 & 2,94 & 6,39 \\
\hline 61 & Mantehage & 1 & 7 & 7 & 7 & 7 & 7 & 0,10 & 1,96 & 0,28 & 0,35 & 0,84 & 2,94 & 6,47 \\
\hline
\end{tabular}

Keterangan : V1= Ukuran luas daratan pulau; V2 = Keragaman dan kondisi ekosistem pesisir; V3= Keberadaan penduduk di pulau; V4 = Aktivitas penduduk pulau dengan negara tetangga; V5 = Jarak/aksesibilitas ke lokasi pusat pertumbuhan ekonomi; V6 = Potensi sumber daya hayati laut untuk wisata bahari

Sumber: Data diolah dari Laporan Direktorat Pendayagunaan Pesisir dan Pulau-Pulau Kecil (2017) dan Direktorat Perencanaan Ruang Laut (2019)

Sehingga banyaknya kelas (k) dihitung dengan rumus $k=1+3,3 \log (N)$, dengan $N=61$ (jumlah pulau potensial untuk pusat pertumbuhan ekonomi), maka diperoleh nilai $\mathrm{k}=7$. Pengkategorian skor PPKT ke dalam 7 kelas menunjukkan ranking kekuatan potensi PPKT sebagai pusat pertumbuhan ekonomi ke depan (Tabel 8).

Berdasarkan hasil analisis skoring 61 PPKT yang potensial untuk dikembangkan menjadi pusat pertumbuhan ekonomi di wilayah perbatasan, maka terdapat 7 (tujuh) kelompok prioritas pengembangan PPKT. Pada kelompok ranking prioritas pengembangan ke-7 terdapat 9 pulau, 10 pulau termasuk ke dalam kelompok ranking prioritas pengembangan ke-6, 14 pulau termasuk ke dalam kelompok ranking prioritas pengembangan ke-5, 17 pulau termasuk ke dalam kelompok ranking prioritas pengembangan ke-4, 3 pulau termasuk ke dalam kelompok ranking prioritas pengembangan ke-3, 4 pulau termasuk ke dalam kelompok ranking prioritas pengembangan ke-2, dan 4 pulau termasuk ke dalam kelompok ranking prioritas pengembangan ke-1. PPKT yang termasuk ke dalam ranking prioritas pengembangan ke-4 s/d ke-7 mencapai jumlah 50 pulau dari total 61 pulau. Sisanya sebanyak 11 pulau termasuk ke dalam ranking prioritas pengembangan ke-1 sampai ke-3.

Memperhatikan kendala pengembangan yang terdapat pada 50 pulau tersebut, antara lain berupa: terdapatnya keterbatasan keragaman ekosistem pesisir, belum adanya kegiatan wisata bahari di pulau tersebut, jarak/aksesibilitas yang masih rendah, dan terbatasnya interaksi penduduk

Tabel 8. Hasil Pengelompokan Prioritas Pengembangan 61 PPKT, 2019.

\begin{tabular}{cccc}
\hline No. & Kelas Ranking PPKT & Jumlah PPKT & Prioritas Pengembangan PPKT \\
\hline 1 & $<1,80$ & 9 & Prioritas 7 \\
2 & $1,81-2,60$ & 10 & Prioritas 6 \\
3 & $2,61-3,40$ & 14 & Prioritas 5 \\
4 & $3,41-4,20$ & 17 & Prioritas 4 \\
5 & $4,21-5,00$ & 3 & Prioritas 3 \\
6 & $5,01-5,80$ & 4 & Prioritas 2 \\
7 & $>5,81$ & 4 & Prioritas 1 \\
\hline
\end{tabular}

Sumber: Data diolah dari Laporan Direktorat Pendayagunaan Pesisir dan Pulau-Pulau Kecil (2017) dan Direktorat Perencanaan Ruang Laut (2019) 
dengan pusat pertumbuhan ekonomi wilayah terdekat. Oleh karena itu, untuk mengembangkan kelimapuluh pulau tersebut diperlukan program, kegiatan, dan penganggaran yang memadai dan berkesinambungan serta terpadu lintas sektor dan lintas level pemerintahan. Program, kegiatan, dan penganggaran tersebut diarahkan untuk memperbaiki kondisi keterbatasan pulau dan untuk meningkatkan potensi daya tarik kegiatan wisata bahari pada 50 pulau tersebut.

Sementara itu, untuk PPKT yang masuk ke dalam kelompok ranking prioritas pengembangan ke-1 sampai dengan ke-3 memiliki potensi yang relatif besar sebagai objek kunjungan wisata bahari, seperti: keragaman dan kondisi ekosistem pesisir, jarak/aksesibilitas ke lokasi pusat pertumbuhan ekonomi wilayah, dan potensi sumber daya hayati laut untuk wisata bahari. Dari kesebelas PPKT yang memiliki potensi relatif besar untuk dikembangkan sebagai objek kunjungan wisata bahari, yaitu: Pulau Tokong belayar, Senua, Mangkai, dan Mantehage. Kendala pengembangan program dan kegiatan wisata bahari di Pulau Tokong Belayar dan Pulau Senua berupa ukuran luas daratan pulau yang kurang dari 100 ribu hektar dan saat ini keduanya tidak memiliki penduduk yang tinggal menetap di pulau. Pulau Mangkai pada saat ini juga belum berpenduduk, sementara itu Pulau Mantehage memiliki ukuran pulau yang kurang dari 100 ribu hektar.

Oleh karena itu, perencanaan program dan kegiatan wisata bahari yang berkelanjutan dan ramah lingkungan pada keempat pulau tersebut perlu memperhatikan 5 hal pokok, yaitu: 1) penetapan rencana pengelolaan zona konservasi keanekaragaman hayati laut pada ekosistem pesisir di sebagian perairan sekitar pulau untuk melindungi, memelihara, memanfaatkan, dan mengawasi pemanfaatan potensi sumber daya hayati laut bagi kegiatan wisata bahari secara berkelanjutan; 2) penetapan rencana pengelolaan zona peruntukan di daratan pulau untuk menjamin pemanfaatan yang sesuai dengan daya dukung dan daya tampung pulau, khususnya yang memiliki ukuran luas pulau kurang dari 100 ribu Ha; 3) penyiapan program promosi dan kemudahan investasi pembangunan pulau untuk meningkatkan daya tarik pulau sebagai lokasi tujuan wisata mancanegara dengan pelibatan masyarakat serta dunia usaha melalui program dan kegiatan yang profitable; 4) pengembangan sistem pengawasan kegiatan pemanfaatan sumber daya di pulau dan perairan di sekitarnya melalui kegiatan perizinan lokasi secara cepat, mudah, dan efisien untuk menjamin kepastian hukum bagi pelaku kegiatan; 5) pembentukan kelembagaan pengelola dalam upaya pengelolaan pembangunan di pulau kecil terluar secara efisien (biaya dan waktu) dan efektif (tujuan sosial, ekonomi, lingkungan, dan kedaulatan).

\section{PENUTUP}

PPKT sebagai pusat pengembangan ekonomi yang ditinjau dari 3 (tiga) kriteria aspek teknis, sosial, dan ekonomi menunjukkan bahwa; (a) dari 111 PPKT diperoleh 61 pulau yang memiliki potensi untuk didorong menjadi pusat pertumbuhan ekonomi wilayah perbatasan ke depan; (b) tingkat kekuatan potensi untuk menjadi pusat pertumbuhan dari 61 PPKT berbeda-beda karena perbedaan potensi ekonomi dan akses dari dan ke PPKT; serta (c) potensi ekonomi yang menjadi basis pengembangan PPKT menjadi pusat pertumbuhan ekonomi adalah kegiatan wisata bahari

61 PPKT diurutkan menjadi 7 kelompok prioritas pengembangan PPKT, yaitu1) 4 pulau merupakan prioritas pengembangan pertama; 2) 4 pulau merupakan prioritas pengembangan ke dua, 3) 3 pulau merupakan prioritas pengembangan ke tiga, 4) 17 pulau merupakan prioritas pengembangan ke empat, 5) 14 pulau merupakan prioritas pengembangan ke lima, 6) 10 pulau merupakan prioritas pengembangan ke enam 7) 9 pulau merupakan prioritas pengembangan ke tujuh. Prioritas pengembangan PPKT sebagai pusat pengembangan ekonomi adalah PPKT yang masuk dalam urutan prioritas pertama sampai ketiga, yang jumlahnya 11 PPKT.

Dalam upaya pengembangan potensi PPKT pada keempat pulau yang merupakan prioritas pengembangan pertama, maka penelitian ini menyarankan: (1) Penetapan rencana pengelolaan zona konservasi keanekaragaman hayati laut pada ekosistem pesisir; (2) Penetapan rencana pengelolaan zona peruntukan di daratan pulau untuk menjamin pemanfaatan yang sesuai dengan daya dukung dan daya tampung pulau; (3) Penyiapan program promosi dan kemudahan investasi; (4) Pengembangan sistem pengawasan kegiatan pemanfaatan sumber daya di pulau dan perairan sekitar pulau; serta (5) Pembentukan kelembagaan pengelola pembangunan di PPKT. Sementara itu, pengembangan PPKT sebagai kawasan wisata bahari harus dilakukan analisis 
ekonomi terkait sumber daya hayati dan ekosistem perairan sekitar PPKT, daya dukung lingkungan, dan daya tampung perairan PPKT.

\section{UCAPAN TERIMA KASIH}

Penulis ingin menyampaikan terima kasih kepada Dirjen Pengelolaan Ruang Laut, KKP dan semua pihak atas dukungan yang diberikan sehingga survei pengumpulan data untuk tulisan ini dapat dilaksanakan pada tahun 2003-2009 dan 2014-2019.

\section{PERNYATAAN KONTRIBUSI PENULIS}

Kontributor utama tulisan ini adalah Suharyanto dan Armen Zulham. Kontributor anggota terdiri dari Muhandis Sidqi, Arif Sudianto, Arif Widianto, Suraji, dan Didit Eko Prasetiyo.

\section{DAFTAR PUSTAKA}

Adiyanto, E., Eidman, E., Adrianto, L. (2007). Tinjauan Hukum dan Kebijakan Pengelolaan Pulau-Pulau Kecil Terluar Indonesia (Studi Kasus Pulau Nipa). Buletin Ekonomi Perikanan VII(2), 51-62. Diunduh dari https://media.neliti.com/media / publications/11028-ID-tinjauan-hukum-dan-kebijakan-pengelolaan-pulau-pulau-kecil-terluar-indonesia-stu.pdf

Agvian, M. (2015). Quo Vadis Strategi Pembangunan Daerah Tertinggal di Indonesia. Deputi Bidang Pembangunan Desa, Daerah Tertinggal, dan Transmigrasi, Sekretariat Kabinet RI. Diunduh dari https://setkab.go.id/quo-vadis-strategi-pembangunan-daerah-tertinggal-di-indonesia

Azwar, A., Hamzah, R., Masbar, \& Syahnur, S. (2013). Economic Growth Disparity among Region in Aceh, Indonesia. Aceh International Journal of Social Sciences, 2(1): 21-31

Bank Indonesia. (2007). Perkembangan Ekonomi Wilayah Perbatasan Provinsi Sulawesi Utara (Kabupaten Kepulauan Talaud). Diunduh dari https://www.bi.go.id/id/publikasi/kajian-ekonomiregional/sulut/Documents c8533639024a23ae00 2a3550320617Boks3.pdf

Bakce, D., Syahza, A., Asmit, B. (2018). Pembangunan Ekonomi Wilayah Perbatasan Antar Negara di Provinsi Riau. Seminar Nasional Pembangunan Pertanian dan Pedesaan, Unri Conference Series: Agriculture and Food Security, (1), 182-189. Diunduh dari https://doi.org/10.31258/ unricsagr.1a24

Butcher, J.G. (2013). The International Court of Justice and the Territorial Dispute between Indonesia and Malaysia in The Sulawesi Sea. Contemporary
Southeast Asia (35) 2. pp. 35-57. DOI: 10.1355/ $\operatorname{cs} 35-2 e$

Chiang, S. (2018). Assesing the Merits of the Urban-Led Policy in China: Spread or Backwash Effect? Journal Sustainability, (10) 451:1-14

Colson, D.A. (2003). Sovereignty over Pulau Ligitan and Pulau Sipadan (Indonesia / Malaysia). The American Journal of International Law, (97) 2. pp. 398-406

Dewitri, A. (2017). Analisis Hubungan Komplementer dan Kompetisi Antar Destinasi Pariwisata (Studi Kasus: 10 Destinasi Pariwisata Prioritas Di Indonesia). Tesis MPKP. FEB UI

Direktorat Perencanaan Ruang Laut. (2019). Profil 111 PPKT Indonesia. Direktorat Jenderal Pengelolaan Ruang Laut. Kementerian Kelautan dan Perikanan. Jakarta

Direktorat Pendayagunaan Pesisir dan Pulau-Pulau Kecil. (2019). 111 Pulau-Pulau Kecil Terluar (PPKT) di Indonesia. Direktorat Jenderal Pengelolaan Ruang Laut. Jakarta. Diperoleh dari https://kkp. go.id/djprl/p4k/infografis-detail/5794-111-pulaupulau-kecil-terluar-ppkt-di-indonesia

Direktorat Pendayagunaan Pesisir dan Pulau-Pulau Kecil. (2017). Laporan Toponimi Pulau Pulau Kecil Terluar Republik Indonesia. Kementerian Kelautan dan Perikanan. Jakarta

Fadjri, A. (2018). Kebijakan Pengelolaan Pulau-Pulau Terluar Di Tinjuau Dari Aspek Kependudukan. Pusat Penelitian Kependudukan LIPI, Indonesia. Jurnal Kebijakan Sosial Ekonomi Kelautan dan Perikanan, 8(1), 39-51

Fareha, N., Victoria, O.A., \& Apriliyanto, F.E. (2019). Dispute International Between Indonesia And Malaysia Seize on Sipadan and Lingitan Island. International Journal of Law Recontruction. III (1). pp: 1 - 10. DOI: 10.26532/ijlr.v3i1.4367

Friedmann, J. (1967). A General Theory of Polarized Development. The Ford Foundation Urban and Regional Advisory Program, Santiago, Chile. Diunduh dari https://repositorio.cepal. org/bitstream/handle/11362/34953/S6700361_ en. . pdf? sequence $=1$ \&isAllowed $=y$

Gavrilă-Paven, I., Bele, I. (2017). Developing A Growth Pole: Theory and Reality. doi: 10.18515/dBEM. M2017.n01.ch22. Chapter: January 2017. Diunduh dari https://www.researchgate.net/ publication/312209513_Developing_a_growth_ pole_theory_and_reality

Kementerian PPS/Bappenas. (2017). Profil dan Analisis Daerah Provinsi Sulawesi Utara 2017. Kedeputian Bidang Pengembangan Regional. Diunduh dari https://simreg.bappenas.go.id/ 
assets/temaalus/document/Publikasi/DokPub/ PRADA PROVINSI_SULAWESI_UTARA.PDF

[KKP] Kementerian Kelautan dan Perikanan. (2013). Biota Perairan Terancam Punah di Indonesia: Prioritas Perlindungan. Direktorat Konservasi dan Jenis Ikan, Ditjen Kelautan, Pesisir, dan Pulau-Pulau Kecil bekerja sama dengan Pusat Penelitian Biologi, Lembaga IImu Pengetahuan Indonesia (ISBN:978-602-7913-08-0)

[KKP] Kementerian Kelautan dan Perikanan. (2016). Rencana Zonasi Kawasan Strategis Nasional Pulau-Pulau Kecil Terluar Pulau Nipa. Direktorat Perencanaan Ruang Laut. Jakarta

[KKP] Kementerian Kelautan dan Perikanan. (2017). Rencana Zonasi Kawasan Strategis Nasional Tertentu Pulau-Pulau Kecil Terluar Pulau Maratua dan Pulau Sambit. Direktorat Perencanaan Ruang Laut. Jakarta

[KKP] Kementerian Kelautan dan Perikanan. (2018). Rencana Zonasi Kawasan Strategis Nasional Tertentu Pulau-Pulau Kecil Terluar Klaster Batam - Bintan - Karimun (Pulau Karimunanak, Pulau Tokonghiukecil, Pulau Pelampung, Pulau Putri, Pulau Batuberantai, Pulau Bintan, Pulau Berakit, Pulau Malangberdaun, dan Pulau Sentut). Direktorat Perencanaan Ruang Laut. Jakarta

[KKP] Kementerian Kelautan dan Perikanan. (2018a). Rencana Zonasi Kawasan Strategis Nasional Tertentu Pulau-Pulau Kecil Terluar Klaster Toli-Toli (Pulau Lingayan, Pulau Solando, dan Pulau Dolangan). Direktorat Perencanaan Ruang Laut. Jakarta

Kusumo, A. T. S. (2010). Optimalisasi Pengelolaan dan Pemberdayaan Pulau-Pulau Terluar dalam Rangka Mempertahankan Keutuhan NKRI. Fakultas Hukum Universitas Sebelas Maret, Surakarta. Jurnal Dinamika Hukum, 10(3)

LPEM UI. (2018). Laporan Akhir. Kajian Dampak Sektor Pariwisata Terhadap Perekonomian Indonesia. Lembaga Penyelidikan Ekonomi dan Masyarakat, Fakultas Ekonomi dan Bisnis. Universitas Indonesia. Salemba. Jakarta, 142

Lehtonen, O., O. Wuori., \& T. Muilu. (2015). Comparing the Extend of the Sread Effects: Rural Urban Commuting in Finnish Working Regions. Journal of Geographic Information System (7), 29-42. doi: http://dx.doi,org/10.4236/jgis.2015.71003

Merrils, J.G. (2003). Sovereignty over Pulau Ligitan and Pulau Sipadan (Indonesia v Malaysia), Merits, Judgment of17 December 2002 The International and Comparative Law Quarterly, (52)3: pp. 797-802
Nurhadi, F. D. C., Mardiyono, Rengu, S. P. (2014). Strategi Pengembangan Pariwisata Oleh Pemerintah Daerah Terhadap Pendapatan Asli Daerah (Studi pada Dinas Pemuda, Olahraga, Kebudayaan dan Pariwisata Kabupaten Mojokero). Jurnal Administrasi Publik, 2(2), 325-331. Diunduh dari http://administrasipublik.studentjournal.ub.ac.id / index.php/jap/issue/view/13

Ogunleye, K. E. (2011). Structural Transformation in Sub-Saharan Africa: The Regional Growth Poles Strategy. Office of The Chief Economic Adviser to The President The Presidency Abuja - Nigeria. Diunduh dari https://www.uneca.org/sites/ default/files/uploaded-documents/AEC/2011 ogunleye-ssa economic_transformation_ through_growth_poles_1.pdf

Pangalasen, A. I. T. (2013). Kajian Pengembangan Ekonomi Wilayah Kawasan Perbatasan Antar Negara Di Kabupaten Kepulauan Talaud. Jurnal EMBA, 1(3), 197-207. Diunduh dari https:// ejounal.unsrat.ac.id/index.php/emba/article/ download/2072/1645

Redjo, S. I., \& As'ari, H. (2017). Pengelolaan Pemerintah dalam Pengaturan Pulau - Pulau Kecil Terluar Indonesia. Jurnal Aksi Reformasi Government Dalam Demokrasi, 5(2), 174-201. doi: 10.34010/ agregasi.v5i2.445

Sekretariat Negara. (2010). Peraturan Pemerintah Nomor 62 Tahun 2010 tentang Pemanfaatan Pulau-Pulau Kecil Terluar. Diunduh dari https://m.hukumonline. com/pusatdata/detail//t4d05d327106b8/nprt/604/ pp-no-62-tahun-2010-pemanfaatan-pulau-pulaukecil-terluar

Speakman, J., \& Koivisto, M. (2013). Growth Poles: Raising Competitiveness and Deepening Regional Integration. World Bank. Diunduh dari http://www3.weforum.org/docs/ACR/2013/ACR_ Chapter2.3_2013.pdf 